\title{
THE IDENTITY CONFLICT OF THE SYMBOLIC DOMINATION DISCOURSE IN THE SHORT STORIES OF MODERN CIVILIZATION
}

\author{
Eka Ugi Sutikno \\ English Education Study Program Teachers Training and Education Faculty of Muhammadiyah \\ University Tangerang Jl. Perintis Kemerdekaan I/ 33 Cikokol, Tangerang-IndonesiaEmail Correspondence: \\ ekaugisutikno@gmail.com
}

\begin{abstract}
In this modern-day, many women have a suitable carrier; however, they often have seemed like a weak person. One of their weaknesses that often shown is the unableness of how to make any decision. These things often happen in real life and stated in the literature, especially in short stories. The Anatomy by Padrika Tarrant and the Otobiografi Gloria by AS Laksana are literary works that are containing the identity conflict of the symbolic domination discourse. The research purpose is to analyze the identity conflict of the symbolic domination discourse in these short stories. The method of this research is using the qualitative descriptive because the subjects are short stories. The result of this research has shown the two main characters of these short stories, which dominated on symbolic and they live in the marginal as the women who have an identity. The conclusion of this research has drawn that women in this modern era still dominated on symbolic and as a weak person.
\end{abstract}

Keywords: Identity, Domination, Women

\section{INTRODUCTION}

When somebody writes on a keyword, as like 'violence' on the browser, he/she will face some definitions from digital dictionaries to world organizations, which intention about humanity's problem. On the same side, this internet media will show or lead every user to the news that somebody is hurting somebody else. Thus, this action also has referenced to the other conflict, i.e., domination (or what Wardhana says, whether physical or symbolic domination (2013: 13)), colonialism, and identity.

Domination action as the description of the people below who dominated will not realize that they are in rough conditions. Besides, sometimes, they will feel that the incident before was caused by their actions in the past. That is why these persons will say, "It is a fate" or in other words, as defenceless and submissive to 
Globish (An English-Indonesian journal for English, Education and Culture)

Vol. 9 No.2 Juli 2020

P-ISSN: 2301-9913, E-ISSN: 2597-9132

DOI: http://dx.doi.org/10.31000/globish.v7i2

the decision-maker. However, by the domination power that ". . symbolic ones, capable of shaking the political and legal institutions which play a part in perpetuating their subordination" (Bourdieu, 1998: ix). Of course, there is a condition, such as a conscious feeling of their situation; they do not want to be dominated or have taken control of the institution.

This subordination will go further to the reality illustration, which was a couple of years ago (October and November 2017); there were some cases of sex abuse harassment, which involved some prominent Hollywood directors and their victims (the actresses). These directors reported as a sexual predator and threatened to get a jail. Unfortunately, some victims were silent until the time will break the curtain. It means that these women zip their mouth in years. Pragmatically, when these victims tell the directors' behaviour to the officer or the public, their job will no longer be suitable. After that, the moviemaker could fire them. This case correlates with Mayer's statements that "Sexual harassment is about power, not sex," even ". . . it has taken women of extraordinary power to overcome the disadvantage that most accusers face" (Mayer, 2017). Thus, the power will able to pick somebody in front of and inside the violence's gate.

Sexual harassment is an action that needs power or dominates other people. This action also is the verbal thing to overlook, which means he/she who dominant and dominated have a conscious as a superior and an inferior. What if the subject lies on the circle of, as like, unconscious that she/she has dominated? This question has a similar condition to Padrika Tarrant's short story, especially Anatomy (2007). It tells about a defenceless character, a university student who had sex with her lecturer. When she knows her womb becomes growing, she no longer to go to the class. Even she leaves the course and finally has a bad score, she always goes to the campus and sometimes meets his lecturer. Indeed, as a medical university student, this pregnancy makes her carrier extraordinarily broken. The character in this work shows that 'she,' as the main character, has no idea (unconsciously), whether in dominated by her lecturer and society.

Even these samples above are on the domination plus power vision; however, they have also followed by colonialism. It means domination and colonial action, 
Globish (An English-Indonesian journal for English, Education and Culture)

Vol. 9 No.2 Juli 2020

P-ISSN: 2301-9913, E-ISSN: 2597-9132

DOI: http://dx.doi.org/10.31000/globish.v7i2

such as a pair of feet. They are walking side by side. Thus, they have a similar tendency to hurt someone or subject outside herself or himself.

Thus, it is not only in real life that domination power and colonialism are happening, but literature also shows the reality by the words. Even literature writing is close to the definition of fiction that it does not occur in real life, on the other hand, Bennet and Royle say ". . . literature is the kind of writing which most persistently and most provocatively engages with the uncanny aspects of experience, thought and feeling" (2004: 35). It is because the literature consists of everyday life. That is why in the literature writing, the reader able to see the different world or the other justice and justification.

When literature draws some domination and colonialism, then the short story can not loose from our sight because this kind of work always shows the reality of the fiction. Anatomy by Padrika Tarrant and Otobiografi by A.S. Laksana are the short stories describing the symbolic violence and domination of the main characters. That is why, in this article, the researcher is going to find out the power and dominated from two short stories above. Two main things in this research should have discussed. The first is how the symbolic order dominated 'I' lyric (read: woman). The second is how the postcolonial discourse has to be a specific problem for 'I' lyric. These things above are not about how good the writer made it and pregnant before marriage is a common problem. It is because this story has an essential issue, i.e., gender, and again, the woman is always to be the victim.

The first character of this short story, especially Anatomy by Padrika Tarrant, is a woman (student) who studied in the medical faculty. She gets herself pregnant. This incident happens when she admires (even after she knew she is pregnant) her lecture; his name is Finn. Her lecturer has described as a man who has an ethical manner, very masculine, good looking, and the last he looks like a god. These appearances indicate why she falls in love with him and giving her genitals to this lecturer.

After they had sex, in the beginning, she became conscious and anxious with her belly, which was keeping the womb. Once, she only brought some pictures, which was she drew for her Finn. However, her lecture became angry because of 
Globish (An English-Indonesian journal for English, Education and Culture)

Vol. 9 No.2 Juli 2020

P-ISSN: 2301-9913, E-ISSN: 2597-9132

DOI: http://dx.doi.org/10.31000/globish.v7i2

those sketches. By these actions, there were some interpretations. First, they were anxious about their condition and, of course, by their cause. Second, Finn and her student, especially 'I' lyric, was to be inferior also to be superior. Unfortunately, these interpretations will have discussed in the next pages below. Finally, this woman will not bring them for him because she worries if she gives them to her idol, she will have expelled by the officer or the men from the campus.

When she feels baby in her womb, she feels like she has to make a distance from her friend in the dorm. This short story, the main character, does not tell why she has to keep away from people around her. Maybe she will not reveal her new identity as a woman who had failed from the university and a young mother. After that, only waste her time by going to the museum and walk around the campus.

The second short story is also the female character as the victim. Her name is Gloria. She told that before her life now was a newborn baby. After that, her grandfather killed him. It was because her mother had an unwed pregnancy. The primary expectation from her grandparents had a grandchild from their first daughter. Even their parents were travelling to other places to get a magic potion or something to make her daughter pregnant. However, this daughter could not have any baby from her married. In the middle of the story, she admitted that she understood why her grandfather had to cut her throat. It was calling, she said. This calling was like whispering, which was happening to kill someone.

On the same side, her grandparents were disappointing for their children. The first child is female. This daughter cannot has a child even got married. The second is a male. Even this son had Islamic School before; however, he had a problem with his life, such as drink any alcohol and suicide.

Moreover, the last is Gloria's mother, who had unwed pregnancy. This story will show the reader that the atmosphere from the main character retold was not any revenge to show. In the last story, the main character had killed since a baby. In the last of the story, also, that this ghost who had murdered by her grandfather. She had told her case by the media. This media is to trance someone and then to write something. This writing form has awakened her spirit to enter the living 
Globish (An English-Indonesian journal for English, Education and Culture)

Vol. 9 No.2 Juli 2020

P-ISSN: 2301-9913, E-ISSN: 2597-9132

DOI: http://dx.doi.org/10.31000/globish.v7i2

body, i.e., A.S. Laksana. She has a memory of how she died and how her mother has not expected to pregnant.

\section{THEORY}

Domination is not the quantity of a group of people or ethnicities, which are surrounded by other people in either one or another place. After that, they live in assimilation. On the same side, it is also not only about binary from the status of the boss (superior) and about employer (inferior) correlation. In Haryatmoko's book, Bourdieu gives the point of view that the way of domination has imposed and suffered by the others as the compliance, the effect of symbolic violence, subtle violence, misperceive, undetectable by the victims (2010: 10). It means there is nothing force action in domination because it has accepted by the dominated subject and the dominant subject. Moreover, the way it is by the unconsciousness.

When someone kills, slams, and punch other people [read: the other], it is not only because he/she was angry with others. Even the action above is part of the crime and where Mayr says “. . crime is simply the action of bad people” (2008: 2); it could be curiosity that maybe something is happening inside the subject's psychology. It means disorder. However, when we face the illustration that someone gives the command and someone else (the other) obediently does something that she/he also wants, indeed, it has a possibility that the first subject is a boss and the second one is the employer. On the other side, these actions are not the final evaluation because they could have referred to domination and power. That is why Haryatmoko says in society's life, there are ones dominant and dominated (2010: 17).

Domination also referred to the discourse that women's position has forced on the cornered, is it in the society or institution. First, for denotation meaning, women as the weak point of view. Unfortunately, they as if accept this stereotype and affirm that male as the superior subject. Finally, they get themselves to the second class and cannot have some voice to make them out to the public as a unique subject. This situation also correlates "... in particular the power relations in which they are held, through schemes of thought that are the product of an 
Globish (An English-Indonesian journal for English, Education and Culture)

Vol. 9 No.2 Juli 2020

P-ISSN: 2301-9913, E-ISSN: 2597-9132

DOI: http://dx.doi.org/10.31000/globish.v7i2

embodiment of those power relations and which expressed in the founding oppositions of the symbolic order" (Bourdieu, 1998: 33-34).

In the symbolic order, the subject will realize that the rule, the stereotype, the world point of view are the building of cognition, and this subject will no doubt three things before because they viewed as part of the absolute rightness. It is what Bourdieu calls as doxa. This term will have explained through an example story such as Dayen gets herself before the zebra crossing and sits in her car. Then, she cannot go straight further, because her eyes already saw the red light is on. Her mind says, if she does not care about the traffic light, she will run her car, and the accident will happen, or the police will give her a ticket. Maybe for the familiar people that stop in front of the red light is an ethical manner, and the subject does not break the rule. On the other side, there is a hidden force and power because the dominant, i.e., government, does not need a weapon or verbal domination power to make the community obey the rule. It just needs the cognition to affirm. Bourdieu also clarifies, "It follows that their acts of perception are acts of practical recognition, doxic acceptance, a belief that does not need to be thought and affirmed as such, and which in a sense 'makes' the symbolic violence which it undergoes" (1998: 34).

Even doxa is the final step of the subject to recognize and accept the domination, however in the process of how the human subject affirms this domination is by habitus. Emirbayer and Johnson in Smith (2007) also have agreed with Bourdieu, "Symbolic violence is lodged in an individual's 'durable principles of judgment and practice' - the habitus." It means that the habitus practices will guide the subject to the activity (or more) that he or she doing in everyday life. It could take an example that they (husbands) are like get up early in the morning and go to the office; tell his wife that salary is on the account bank and give some money to his wife; (in Indonesia) when the Friday has come every employer has to wear white baju koko (long-sleeved collarless shirt). In other words, these activities correlate with symbolic violence and doxa.

Because doxa is the peak of symbolic violence, this doxa will show how the dominant subject can reach, hold, and spread the power with the symbolic game, 
Globish (An English-Indonesian journal for English, Education and Culture)

Vol. 9 No.2 Juli 2020

P-ISSN: 2301-9913, E-ISSN: 2597-9132

DOI: http://dx.doi.org/10.31000/globish.v7i2

which has succeeded in influencing the dominated's cognition until the human subject lost his or her critical thinking by the dominant. The irony thing is the dominated see him or herself as the same as the dominant. The human subject that has been intimidated, however, he or she does not feel it. This situation calls as doxa (Wattimena, 2012).

The doxa is a symbolic practice that a person who dominated has consciousness to accept the dominating program. Thus, this discourse will show the subject's identity that has drawn as the concept of weak and subaltern. The self cannot give the status him or herself, because Butler says "that identity is performatively constituted by the very 'expressions' that are said to be its results" (1999: 33). This performative is pointing to how the subject's appearance to the other people. That is why the other will evaluate his or her appearance. Besides, the presence itself is not about the dress, but how the subject's attitude.

On the same side During says that "Identities, then, are not given in terms of what individuals are as a whole, but in terms of more or less arbitrarily selected features that they possess." It means identity processing has not any final addressing people. He also explains, "For the most part, individuals have little power to choose what features will have used to identify them - these are determined socially, from the outside" (2005: 145).

When identity is not stable to identify people, then identity is taken to mean also aggressively constructed in an instant. Then gender identity, defined as a person's understanding of themselves as being feminine or masculine regardless of their biological sex and also identity needs the presence of the subject (Wood and Eagly, 2015; Niven, Jose, Rawstorne \& Nathan, 2017; Sutikno and Supena, 2016). To understand the subject, someone needs the presence to show from others. It is why the phenomenon of the subject has angles to comprehend because others' perspective who looked at the subject.

For the ideal perspective, that identity concerns about appearance frequently in respondents' motivations, as did issues of relative identities with men, and thereby encounter within themselves became noteworthy (P and Unnithan, 2017: 36). In gender context, identity theorists also maintain that individuals pursue 
Globish (An English-Indonesian journal for English, Education and Culture)

Vol. 9 No.2 Juli 2020

P-ISSN: 2301-9913, E-ISSN: 2597-9132

DOI: http://dx.doi.org/10.31000/globish.v7i2

behaviours. These behaviours are about reliable with their gender identity. The degree that they embrace masculinity and femininity also one of the practices. Furthermore, besides, avoid conduct that violates the meanings associated with their gender identity (Jun \& Kyle, 2012: 354).

What is vital for understanding identity processes is not how the structure of society views authority figures or official familial members per se, but rather how proximal agents nurture and socialize children. Families are the proximate agents of identity socialization; both identity theory and identity control theory can explain the socialization process regardless if these agents fall within the traditional boundaries of "family," or if they are qualitatively different (243).

The identity is a social phenomenon, which starts with the identity formation process through interaction with the 'other' or against the 'other.' The individual tends to internalize and behaviours practice, values, and norms of the society where he or she has lived in, to provide his or her psychological and physical safety. In this way, to obtain an identity, one must either recognize oneself with someone and or be apparent as identical to someone else. The continuous and permanent internalization processes of the social setting have resulted in the construction of individual identity within a social dimension (İnaç and Ünal, 2013: 223).

\section{METHODS}

The method of this research is using the qualitative descriptive because the subjects are short stories. In another sentence, it means that this method is related to the judge's value of works. Semi also assures that the qualitative methods have based on the interaction of inter-conception and comprehend the profound meaning inside (Semi, 2012: 11). The data that has collected from the sentences of short stories are Anatomy by Padrika Tarrant and Otobiografi Gloria by A.S. Laksana. After researchers read the data based on heuristics and hermeneutics, the data will have classified on the domination conflict and identity.

\section{DISCUSSION}


Globish (An English-Indonesian journal for English, Education and Culture)

Vol. 9 No.2 Juli 2020

P-ISSN: 2301-9913, E-ISSN: 2597-9132

DOI: http://dx.doi.org/10.31000/globish.v7i2

DOMINATION OF ANATOMY BY PADRIKA TARRANT

The symbolic domination is not about the form of afraid to someone. It is about the subject which dominated by attraction and power. Finn, as her lecturer, also has the authority to make the student, especially 'I' lyric, obey his words. The domination action can have seen in this quotation below.

"My tutor was a prophet, you know, with silver hair. He said we were to call him Finn: no standing on ceremony. At the first dissection class I was worried that I might disgrace myself somehow, vomit perhaps; the thought had scared me. But, when Finn's long hands laid out the digestive tract, I was euphoric, having glimpsed the universe" (Tarrant, 2007).

The 'I' lyric is on the unconscious such as 'euphoric' and 'having glimpsed the universe' are the action of symbolic domination. These forms are making them static and only obey the phenomena. On the same side, this character as if she cannot move away, because the male of her tutor is an idol. That is why she dreams about him.

"At half term he asked to see me. There was something in his look, something peculiar; at the time I misread it. I was anxious, of course, convinced that I had done something wrong. I barely slept that night; I passed the time in bed with my textbook, revising, as if I might get through 'til morning, if only I could learn enough. I dreamed of Finn, for just a moment. His teeth were very white. I woke, startled, with my cheek against a diagram, when one of my housemates flushed the toilet" (Tarrant, 2007).

Commonly, the idol is deemed perfect by the fan. However, the idolize drawing above has represented that the other be on her side and mind. This existence makes the subject always thinks about Finn, and Finn's atmosphere has surrounded her. 
Globish (An English-Indonesian journal for English, Education and Culture)

Vol. 9 No.2 Juli 2020

P-ISSN: 2301-9913, E-ISSN: 2597-9132

DOI: http://dx.doi.org/10.31000/globish.v7i2

The other existence who idolized by the main character is to be the central need because she has to meet her tutor and love. On the other side, in this action, she has a role as a hunted person and may have a desire to dominating the other, especially Finn. The activity below will have represented as the narrative of the necessity expectation.

“When Finn came past today, he didn't see me. I saw him though: he was glistening red and grey and blue; the bones in his face were the soft yellow of piano keys. I saw the jump of his oesophagus as he swallowed, and then I ducked behind a lime tree" (Tarrant, 2007).

This face describing by the main character, furthermore, is represented by thirsty and longing for Finn as well. However, this is watching the action, especially in “. . . he didn't see me." has a different perspective way, because 'I' lyric seems like to hide from her tutor. It means that domination has surrounded the subject and her afraid to find out. Besides that, there is a sameness in the quotation below.

“I didn't go home right away. My housemates would all be there, arguing and eating toast and watching children's TV. I found myself at the Museum instead, hunting among the jars and plastic anatomical models, frantically looking for something. It got dark, and the cleaner came in and cleared her throat, but I still hadn't found it, so I went to the house and crept up to my room" (Tarrant, 2007).

In the first sentence, she says that she did not go home because of her friends around the boarding house. There is clue domination from others, i.e., she has to creep up to her room. It means that she has to hide what is that thing inside her body. They will be known her body, and they will judge her as they like. It also as domination from the other.

When the university student has not any problem with his or her lecturer then, maybe, he or she will greet the lecturer or enter the classroom without any 
Globish (An English-Indonesian journal for English, Education and Culture)

Vol. 9 No.2 Juli 2020

P-ISSN: 2301-9913, E-ISSN: 2597-9132

DOI: http://dx.doi.org/10.31000/globish.v7i2

worry. On the other side, the main character of this short story has a fear of feeling when she comes into the Lecture Theatre.

"Sometimes I would creep into the Lecture Theatre and sit at the back. Sometimes, Finn would catch my eye, and then flick quickly back to the whiteboard. For a long time, I wondered why he didn't just have me thrown out; then it dawned on me that he was afraid of me, of the secret" (Tarrant, 2007).

If she does not creep into the class, then there is a lousy possibility, i.e., she will kick out from the lecture. Yes. It is going to be gossiping between the student, and the last is a shameful feeling. Then, their relation will be exposed. It also has a dangerous situation between Finn and 'I' lyric. Finally, the domination result from Finn as a tutor and a power will threaten her to attend the class and university. It can have seen in “These days I'm much more discreet. I wouldn't like to be banned from the university; there isn't really anywhere else to go. So, I'm polite, friendly to the refectory staff; I give them cards at Christmas. They think I'm rather sweet" (Tarrant, 2007).

The symbolic domination is an evil domination action without the other feel it. That is why 'I' lyric cannot tell that Finn has to take any responsibility. On the same side, the subject will recognize that she will do something by herself. It is going to make her better and balance. The quotation below is drawing how symbolic domination works.

"There is death in the museum, and order too, that gives it balance. Every pain is catalogued, lined up, made pure and clean in glass cases and bell jars, until it's hardly a pain at all. There is every syndrome here except my own; I have looked: carefully; scientifically; systematically. There aren't any secrets in the Path Museum. Even so, it's nice inside, and out of the rain on wet days. I am at home here. My secret belongs here too" (Tarrant, 2007).

\section{DOMINATION OF OTOBIOGRAFI GLORIA BY A.S. LAKSANA}


Globish (An English-Indonesian journal for English, Education and Culture)

Vol. 9 No.2 Juli 2020

P-ISSN: 2301-9913, E-ISSN: 2597-9132

DOI: http://dx.doi.org/10.31000/globish.v7i2

The domination is not also always do by a personal subject; however, it could be by the community. This community will recognize someone who has lacked attitude. It means when someone has a child before marriage, then he or she will be stigmatized as the wrong person. It will draw in “... ibuku belum menikah dan tetangga-tetangga tentu akan menggunjingkan perempuan yang hamil tanpa menikah" (Laksana, 2013: 16). By this description that each subject, especially woman, in every community has to keep her manner and has to marry someone to get a child.

'I' lyric also tells about how her grandfather (Bob) stands on the dominated line and does not argue with what Leli's (her grandmother) says about 'cacing' (her mother) as can be seen in the quotation that "Angan-angan Bob untuk menjadikan ibuku seorang penari balet tidak pernah disetujui oleh Leli, sebab hal itu mengingatkannya pada perempuan yang pernah menjadi pacar Bob. 'Lebih baik ia menjadi pegawai bank,' kata Leli" (Laksana, 2013: 18). The determent action by Leli is a domation program to make Bob cannot go further do his motive, i.e., to make little 'cacing' as a ballerina.

There was a stigma when someone was pregnant before marriage, i.e., she cannot have a job. In this case, the woman has to perfect and keep her virginity. The domination rule has a connection with how subject stigmatized by the concept of badness, especially when someone has a child before marriage. In the end, a subject like this cannot have a job. There are some words to "Ketika usianya tiga puluh dan menggendong janin di dalam rahimnya, ibuku sudah tidak bisa menjadi apa pun: karyawan bank atau penari balet" (Laksana, 2013: 19). The community ethic has the power to control the virginity because it is part of the standard to accept by society and company.

Bob has dominated by the community that pregnant before marriage is a scandal that ashamed. That is why he has not any desire to come out of his house. On the other side, Bob and Leli's community also judge them as persons who have a curse, because they do not ask for something to God. The words below have represented that they have cursed. 
Globish (An English-Indonesian journal for English, Education and Culture)

Vol. 9 No.2 Juli 2020

P-ISSN: 2301-9913, E-ISSN: 2597-9132

DOI: http://dx.doi.org/10.31000/globish.v7i2

"Pada dua-tiga bulan menjelang kelahiranku, aku menyaksikan keadaan

Bob yang makin mengharukan. Ada tetangganya yang pernah mengatakan bahwa kehamilan ibuku adalah kutukan yang harus diterima oleh Bob dan Leli karena mereka suka berdoa di tempat-tempat keramat. Bob tidak pernah mendengar sendiri omongan itu; ia nyaris tidak pernah keluar rumah sejak dua-tiga bulan menjelang kelahiranku" (Laksana, 2013: 19).

The sacred places and community gossip are the central discourse to dominate someone. Besides, these things are a weapon which easies to dominate another. That is why Bob and Leli have seemed lack by the community.

The most prominent to see is the action of Bob as the power holder in the family. This action refers to the symbolic domination of the doxa (the accepting domination) by the 'I' lyric. It seen in "Di sana, ketika kami hanya berdua, ia membisikkan padaku ilham yang baru diterimanya. Aku ingin menjawab silakan, tetapi tidak jadi kusampaikan jawaban itu" (Laksana, 2013: 20). The whispering has accepted and affirmed by ' $\mathrm{I}$ ' lyric. The doxa discourse also will show in the same action these have shown below.

“Aku memahami apa yang ia lakukan; kakekku hanya menjalankan sebuah ilham. Tapi aku mati malam itu, sebab ia bukan nabi dan karena itu tak ada malaikat yang datang ke pekarangan untuk menukar tubuhku dengan kambing atau kelinci atau binatang apa pun. Nyawaku terbang ke langit dengan membawa satu keinginan: menceritakan kisah ini kepadamu" (Laksana, 2013: 21).

For Bob, based on the divine inspiration, the best way is killing someone close, i.e. Gloria. The action above also can be categorized as doxa, because 'I' lyric affirm of ending someone's life and it is a fittingness. When her grandfather got to jail, Gloria reaffirms that "Mereka [the police officers] tidak seperti aku; mereka tidak mengerti bahwa apa yang dilakukan oleh kakekku hanyalah mematuhi sebuah ilham" (Laksana, 2013: 21). This action also a doxa. 
Globish (An English-Indonesian journal for English, Education and Culture)

Vol. 9 No.2 Juli 2020

P-ISSN: 2301-9913, E-ISSN: 2597-9132

DOI: http://dx.doi.org/10.31000/globish.v7i2

\section{IDENTITY OF ANATOMY BY PADRIKA TARRANT AND OTOBIOGRAFI GLORIA BY A.S. LAKSANA}

From the domination discourses above, there is a similarity identity to show, which is accepting the domination. This domination practice makes them dull and cannot fight for their rights. On the same side, doxa, as the method of allowing the domination from the main characters do is having a passive and cannot have any critical thinking. Indeed, there is a verbal communication to show that Gloria has accepted domination. However, 'I' lyric in the Anatomy by Padrika Tarrant has the implicit way to show that she has received the domination.

\section{CONCLUSION}

The main character from Anatomy by Padrika Tarrant and Otobiografi Gloria by A.S. Laksana has an important role, especially for their actions in the story. Their position gender as a female cannot doubt, because they tell their story. Unfortunately, the female on these short stories inclines as dull and passive. These things recognize as the form of accepting domination by the other. This acceptance has done unconsciously or identify that the subject has dominated by others. In the end, this action also will harm them in the psychology and social way. And

\section{REFERENCES}

Bourdieu, Pierre. 1998. Masculine Domination. transl. Richard Nice. USA: Stanford University Press.

Bennet, Andrew and Nicholas Royle. 2004. An Introduction to Literature, Criticism and Theory. 3rd Edition. Great Britain: Pearson Education Limited.

Butler, Judith. 1999. Gender Trouble (Feminism and the Subversion of Identity). NY: Routledge.

Carter, Michael J. 2014. “Gender Socialization and Identity Theory". In Social Sciences. 3, 242-263; doi:10.3390/socsci3020242. 
Globish (An English-Indonesian journal for English, Education and Culture)

Vol. 9 No.2 Juli 2020

P-ISSN: 2301-9913, E-ISSN: 2597-9132

DOI: http://dx.doi.org/10.31000/globish.v7i2

During, Simon. 2005. Cultural Studies (A Critical Introduction). NY: Routledge.

Haryatmoko. 2010. Dominasi Penuh Muslihat (Akar Kekerasan dan Diskriminasi).

Jakarta: PT. Gramedia.

İnaç, Hüsamettin and Feyzullah Ünal. 2013. "The Construction of National Identity in Modern Times: Theoretical Perspective". In International Journal of Humanities and Social Science. Vol. 3 No. 11; June 2013.

Jun, Jinhee \& Gerard T. Kyle. 2012. “Gender Identity, Leisure Identity, and Leisure Participation". In Journal of Leisure Research. Vol. 44, No. 3, pp. 353-378.

Laksana, A.S. 2013. Murjakung: Cinta yang Dungu dan Hantu-hantu. Jakarta Selatan: GagasMedia.

Mayer, Jane. 2017. “Anita Hill on Weinstein, Trump, and a Watershed Moment for Sexual-Harassment Accusation". http://www.newyorker.com/news/newsdesk/anita-hill-on-weinstein-trump-and-a-watershed-moment-for-sexualharassment-accusation. Downloaded on November 3, 2017.

Mayr, Andrea. 2008. "Introduction (Power, Discourse and Institutions)". In Andrea Mayr (edt). Language and Power (An Introduction to Institutional Discourse). London: Continuum International Publishing Group.

Niven, Hamish, Hayden Jose, Patrick Rawstorne \& Sally Nathan. 2017. 'They Love Us Just the Way They Love a Woman': Gender Identity, Power and Transactional Sex Between Men Who Have Sex with Men and Transgender Women in Timor-Leste. DOI: 10.1080/13691058.2017.1388928.

P., Ranjitha G. \& Anandakuttan B. Unnithan. 2017. "Self and Identity of Being an Ideal Woman (An Exploratory Qualitative Study)”. In IIM Kozhikode Society \& Management Review. 7(1) 33-44.

Oyserman, Daphna, Kristen Elmore, George Smith. 2012. "Self, Self-Concept and Identity." In Mark R. Leary, June Price Tangney (edt). Handbook of Self and Identity. NY: The Guilford Press.

Smith, Katie. 2007. "Pierre Bourdieu - Challenging Symbolic Violence and the Naturalisation of Power Relations". http://www.eir.info/2007/12/22/pierre-bourdieu-\%E2\%80\%93-challenging-symbolic- 
Globish (An English-Indonesian journal for English, Education and Culture)

Vol. 9 No.2 Juli 2020

P-ISSN: 2301-9913, E-ISSN: 2597-9132

DOI: http://dx.doi.org/10.31000/globish.v7i2

violence-and-the-naturalisation-of-power-relations/. downloaded on 05 Desember 2017.

Sutikno, Eka Ugi and Ahmad Supenda. 2016. “Identitas Dalam Novel 'Maryam' Karya Okky Madasari”. In Jurnal Membaca. Vol. 1, No. 1 April 2016. 39-58.

Semi, M. Atar. 2012. Metode Penelitian Sastra. Bandung: Angkasa Bandung.

Tarrant, Padrika. 2007. Broken Things. United Kingdom: Salt Publishing.

Wardhana, Veven Sp. 2013. Budaya Massa, Agama, Wanita. Jakarta: PT. Gramedia.

Wattimena, Reza A.A. 2012. "Berpikir Kritis bersama Pierre Bourdieu (Filsuf dan Sosiolog asal Prancis)". https://rumahfilsafat.com/2012/04/14/sosiologikritis-dan-sosiologi-reflektif-pemikiran-pierre-bourdieu/. downloaded on 05 Desember 2017.

Wood, W., and A. Eagly. 2015. "Two Traditions of Research on Gender Identity.” In Sex Roles 73 (11-12): 461-473. 